\title{
$\mathrm{Al}-\mathrm{Mg}-\mathrm{Si}$ 합금의 초기 석출물이 비대칭 압연에 의한 전단변형에 미치는 영향 :집합조직과 성형성

\author{
채원기 ${ }^{1} \cdot$ 김봉규 $^{1} \cdot$ 이종범 ${ }^{2} \cdot$ 한준현 ${ }^{1, *}$ \\ 1 충남대학교 신소재공학과 \\ 2 한국생산기술연구원 융합공정소재그룹
}

\section{Effects of Initial Precipitate on Shear Deformation during Asymmetric Rolling of Al-Mg-Si Alloy: Texture and Formability}

\author{
Wonkee Chae', Bong-Kyu Kim¹, Jongbeom Lee ${ }^{2}$, and Jun Hyun Han ${ }^{1, *}$ \\ ${ }^{1}$ Department of Materials Science \& Engineering, Chungnam National University, Daejeon 34134, Republic of Korea \\ ${ }^{2}$ Advanced Process and Materials Group, Korea Institute of Industrial Technology, Inchon 21999, Republic of Korea
}

\begin{abstract}
Al-Mg-Si alloy was rolled asymmetrically at several temperatures to apply shear deformation, and the effects of the initial precipitate on shear deformation, texture evolution, formability, and plastic anisotropy were studied. Texture was analyzed using a EBSD, and the formability and plastic anisotropy of the specimen were evaluated using the $\bar{r}$ value and $\Delta r$ value calculated from the plastic strain ratio (r-value) which was determined from the change in the length of the specimen during tensile deformation. Asymmetric rolling induces a larger equivalent strain than symmetric rolling, and the equivalent strain increases as the asymmetric rolling temperature increases. When a specimen with peak-aged initial precipitates was asymmetrically rolled, less shear deformation occurred at room temperature than in a solution-treated specimen without initial precipitates. In contrast, a larger shear deformation occurred at high temperatures $\left(500^{\circ} \mathrm{C}\right)$. With asymmetric rolling at room temperature, the specimens without initial precipitates had higher formability and lower plasticity, while for asymmetric rolling at high temperature, the specimens with initial precipitates had higher formability and lower plastic anisotropy. This is due to the $<111>/ / \mathrm{ND}$ texture, such as $\{111\}<110>$ and $\{111\}<112>$ orientation that has similar and high $r$-values at $0^{\circ}, 45^{\circ}$, and $90^{\circ}$ to the rolling direction, developed by the shear deformation that occurred during asymmetric rolling.
\end{abstract}

(Received August 25, 2020; Accepted August 26, 2020)

Keywords: Al-Mg-Si alloy, asymmetric rolling, precipitate, shear deformation, texture, formability

\section{1. 서 론 \\ 지구온난화를 일으키는 주범인 이산화탄소는 석유나 석} 탄과 같은 화석연료가 연소될 때 가장 많이 발생된다. 전 세계적으로 지구온난화 현상이 가속화됨에 따라 이산화탄 소와 같은 온실가스 배출량 및 자동차 연비에 대한 규제를 만들어 온실가스 배출량을 감소시키기 위해 노력하고 있다. 이러한 노력의 일환으로 자동차 메이커들은 자동차의 연비

- 채원기·김봉규: 석사과정, 이종범: 연구원, 한준현: 교수 *Corresponding Author: Jun Hyun Han [Tel: +82-42-821-5633, E-mail: jhhan@cnu.ac.kr] Copyright (C) The Korean Institute of Metals and Materials
를 향상시키기 위해 엔진의 성능을 향상시키거나, 공기역 학적으로 차량을 디자인하거나, 자동차를 경량화 하는 방 법 등을 채택하고 있다 [1-7]. 하지만 엔진의 성능 향상은 효과에 비해 많은 비용이 소요되고, 디자인 개선은 다양한 용도의 차량에 일괄적용하기가 어려운 문제점이 있다. 따 라서 경량화를 통해 연비를 향상시키는 방법이 가장 현실 적인 대안으로 채택되고 있다 [4-7].

자동차용 경량금속소재로서 각광받는 알루미늄은 지각구 성원소 중 산소와 규소 다음으로 많으며 비중이 철의 약 $1 / 3$ 수준 $\left(2.7 \mathrm{~g} / \mathrm{cm}^{3}\right)$ 으로 경량성이 탁월하다. 알루미늄 합금 중 $6 \mathrm{xxx}$ 계 합금은 주로 $\mathrm{Mg}$ 과 $\mathrm{Si}$ 이 첨가된 합금으로 강도 와 내식성이 우수한 대표적인 구조용 소재이며 시효처리에 
의해 기계적 특성이 향상될 수 있다 [8-16]. 체심입방구조 (body centered cubic, $\mathrm{BCC}$ )를 갖는 스틸은 냉간압연에 의해 $\{111\}<110>,\{111\}<112>$ 와 같은 $<111>/ / \mathrm{ND}$ 집합 조직의 발달이 용이하지만 면심입방구조(face centered cubic, FCC)인 알루미늄은 냉간압연에 의해 <111>//ND 집합조직의 발달이 어렵고 Brass, Copper, $\mathrm{S}$ 방위와 같은 $\beta$-섬유집합조직의 발달로 인해 낮은 성형성을 가지며 높은 소성이방성에 의한 귀발생 (earing)과 같은 성형결함이 쉽 게 발생된다 $[17,18]$. 이러한 결함은 후 가공을 통해 제거 될 수 있지만 공정이 추가됨에 따라 생산 비용이 상승하게 된다. 따라서 알루미늄 합금의 성형성을 향상시키고 소성 이방성을 감소시키기 위해서는 알루미늄합금 내 <111>// $\mathrm{ND}$ 집합조직의 발달이 매우 중요하다.

지금까지 금속의 결정립 미세화에 의한 강도와 성형성 (연 신율)의 동시 향상을 위해 equal channel angular pressing (ECAP), high pressure torsion (HPT)와 같은 강소성가공 공정들이 많이 연구된 바 있다 [19-22]. 하지만 ECAP는 연속가공과 판재가공이 불가능하며 HPT는 제품의 사이즈 에 한계가 있다. 일반적으로 결정립이 미세화 되면 강도와 연신율의 동시 증가에 의해 인성이 향상되는데 이 때 연신 율의 증가보다는 강도증가 효과가 더 크다. 즉, 결정립 미 세화에 의한 연신율 증가는 기대 만큼 크지 않다. 따라서 알루미늄의 성형성을 향상시키기 위해서는 연신율 증가보 다는 다른 방법이 요구되는데 이것이 바로 집합조직의 제 어이며, 집합조직 제어는 판재의 성형성 향상뿐만 아니라 소성이방성의 감소에도 매우 효과적이다.

알루미늄과 같은 $\mathrm{FCC}$ 에서 <111>//ND 집합조직은 전단 변형에 의해 발달될 수 있다. 그러므로 알루미늄의 결정립 을 미세화 시키거나 전단집합조직을 발달시키기 위해 몇몇 연구자들은 비대칭 압연을 도입한 바 있다. 비대칭 압연이 란 상부롤과 하부롤의 반경 또는 회전속도를 다르게 하여 압연하는 것을 말한다 [23-28]. 압축변형만 받는 대칭압연 에 비해 비대칭압연의 경우 판재는 압축변형 뿐만 아니라 전단변형도 함께 받는다. 이러한 비대칭압연을 통한 전단 변형에 의해 < $111>/ \mathrm{ND}$ 집합조직이 발달하게 되며 발달된 $<111>/ \mathrm{ND}$ 집합조직에 의해 알루미늄 판재의 성형성이 향 상되고 소성이방성이 감소하게 된다. $\mathrm{Kim}$ 등[26] 은 6061 알루미늄 합금을 비대칭압연한 후 시효처리 함으로써 결정 립 크기 감소와 나노 크기의 석출물 형성에 의해 높은 강
도를 갖는다는 결과를 발표하였다. Magalhães 등[27] 은 6061 알루미늄 합금을 극저온에서 비대칭 압연하여 결정 립미세화 효과와 압연 후 시효처리에 따른 기계적 성질과 미세조직을 분석하였다. 또한 Jiang 등[28] 은 순수 알루미 늄의 대칭압연과 비대칭압연에 따른 미세구조와 기계적 특 성을 비교하였다. 비대칭압연과 같은 전단변형은 판재의 미 세조직에 의해 영향을 받게 되는데 전단변형량은 그 중에 서도 석출상과 같은 제 2 상에 크게 의존한다. 특히 $6 \mathrm{xxx}$ 계 알루미늄 합금은 석출경화형 합금으로 $\mathrm{Mg}_{2} \mathrm{Si}$ 와 같은 석출 물이 다량 존재하게 되므로 $6 \mathrm{xxx}$ 계 알루미늄 내에 존재하 는 석출물이 전단변형에 미치는 영향에 대해 고찰하는 것 은 큰 의미가 있다. 하지만 지금까지는 석출물이 비대칭압 연에 의한 전단변형과 그에 따른 집합조직에 미치는 영향 에 대해서는 연구된 바가 거의 없다.

따라서 본 연구에서는 6061 알루미늄 합금 판재의 전단 집합조직 발달을 위해 비대칭압연을 실시하였으며 비대칭 압연 시 변형 전 존재하는 초기석출물이 전단변형에 미치 는 영향에 대해 연구하였고, 전단변형에 의한 집합조직 발 달이 판재의 성형성과 소성이방성에 미치는 영향에 대해 고찰하였다. 또한 초기석출물이 존재할 때 비대칭압연온도 가 전단변형에 미치는 영향에 대해 고찰하였으며 초기석출 물이 없는 경우와 비교 분석하였다.

\section{2. 실험방법}

\section{1 열처리 및 압연}

본 연구에서는 동양 $\mathrm{AK}$ 코리아(주)에서 구입한 $4 \mathrm{~mm}$ 두께 를 갖는 6061 알루미늄 합금 판재를 사용하였으며 합금의 조성은 표 1 과 같다. 그림 1 은 본 연구에서 사용된 시편 들의 열처리 및 압연조건을 나타낸다. 구입한 판재에 이미 존재하고 있는 석출상을 재고용 시키기 위해 $550{ }^{\circ} \mathrm{C}$ 에서 5 시간 동안 용체화 처리 후 수냉하였다. 초기석출물이 전단 변형에 미치는 영향을 알아보기 위해 시효처리한 시편과 시효 처리하지 않은 시편 모두 준비하였다. 시효처리는 경 도가 가장 높은 peak aging 조건을 선택하였다. 시효온도 는 $180{ }^{\circ} \mathrm{C}[10-14]$ 로 고정하였으며 $180{ }^{\circ} \mathrm{C}$ 에서 6061 알루 미늄 합금의 peak aging 시간을 알기 위해 시효처리 시간 에 따른 경도 값을 분석하였으며 그 결과를 그림 2에 나 타내었다. 그림 2에서 알 수 있는 것과 같이 9시간 열처

Table 1. Chemical composition of 6061 aluminum alloy

\begin{tabular}{cccccccccc}
\hline Element & $\mathrm{Mg}$ & $\mathrm{Si}$ & $\mathrm{Fe}$ & $\mathrm{Cu}$ & $\mathrm{Cr}$ & $\mathrm{Mn}$ & $\mathrm{Ti}$ & $\mathrm{Zn}$ & $\mathrm{Al}$ \\
\hline Content $(\mathrm{wt} \%)$ & 0.977 & 0.572 & 0.402 & 0.275 & 0.238 & 0.052 & 0.044 & 0.005 & $\mathrm{Bal}$ \\
\hline
\end{tabular}




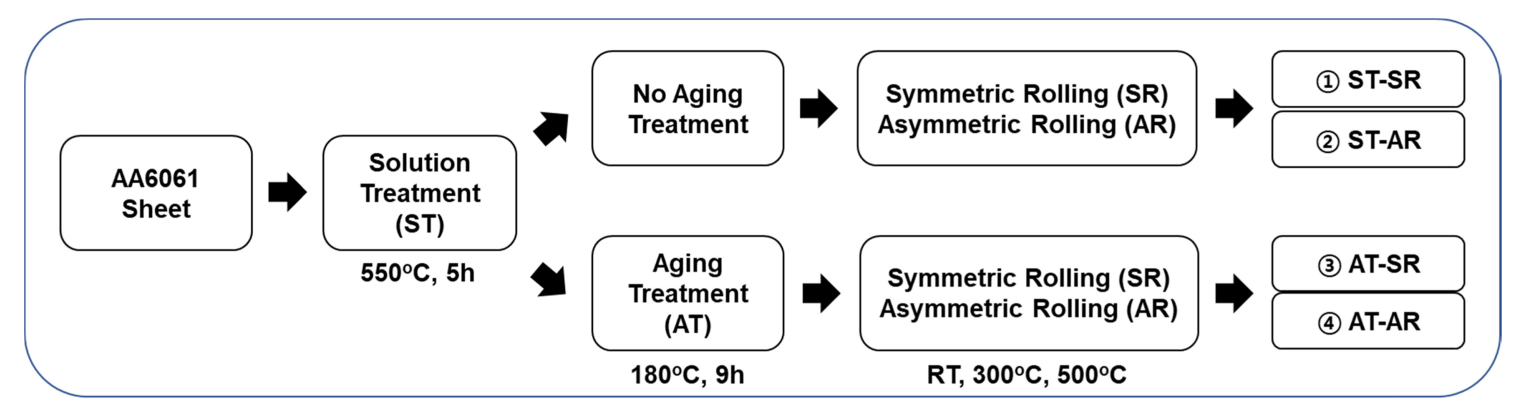

Fig. 1. Fig. 1. Heat treatment and rolling routes to prepare the $6061 \mathrm{Al}$ alloy sheets having different precipitation behaviors.

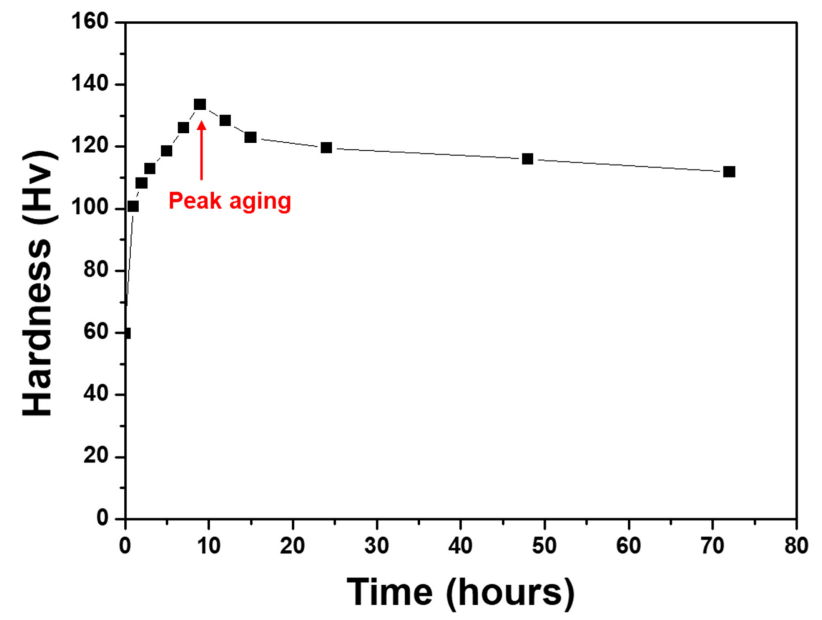

Fig. 2. Variation in Vickers hardness value with aging time at $180^{\circ} \mathbf{C}$.

리 시 가장 높은 경도 값을 보였으므로 본 연구에서는 시 효처리 조건을 $180{ }^{\circ} \mathrm{C}$, 9시간으로 정하였다. 시효 처리된 알루미늄합금 판재는 비대칭압연에 의해 전단변형이 가해 졌으며 비교를 위해 대칭압연도 함께 진행되었다. 압연에 사용된 합금 판재의 크기는 $100 \mathrm{~mm}(\mathrm{~L}) \times 50 \mathrm{~mm}(\mathrm{~W}) \times 4$ $\mathrm{mm}(\mathrm{T})$ 였으며 압연 공정조건을 그림 3에 나타내었다. 그림 3 에서 알 수 있는 바와 같이 비대칭압연 시 상부롤과 하부 롤의 롤 크기는 같았으며 롤 속도비는 $2: 1$ 로서 상부롤의 속도가 2배 빨랐다. 압연 시 압연롤에 의한 시편의 냉각을 최소화하기 위해 압연은 1패스만 실시하였으며 압하율은 $50 \%$ 로 고정하였고 압연 후 시편의 최종 두께는 $2 \mathrm{~mm}$ 이었 다. 압연 시 윤활유 양의 영향을 없애고 롤과 시편과의 미 끄러짐 억제에 의한 전단변형 촉진을 위해 윤활유는 사용 하지 않았다. 또한 압연 온도에 따른 전단변형과 집합조직 의 변화를 알아보기 위하여 압연온도는 상온, $300{ }^{\circ} \mathrm{C}$, $500{ }^{\circ} \mathrm{C}$ 로 변화되었으며, 각 열처리 및 압연조건에 따른 시 편들의 명칭을 표 2에 정리하여 나타내었다. 압연 후 시편 은 자연시효 또는 어닐링 발생을 억제하기 위해 수냉 후

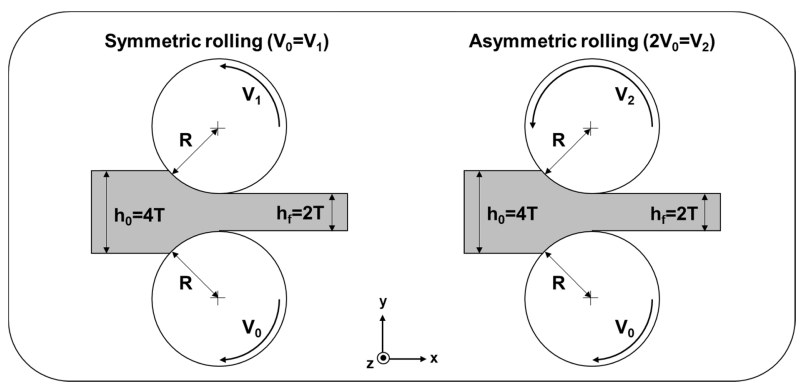

Fig. 3. A schematic picture showing the symmetric and asymmetric rolling process.

냉동 보관되었다.

\section{2 등가변형률 $\left(\varepsilon_{e q}\right)$ 계산}

비대칭압연에 의한 변형률 변화를 분석하기 위해 압연 전에 판재의 옆면 (TD면)에 $1 \mathrm{~mm}$ 간격으로 수직, 수평하게 그리드 (grid)를 표시하였으며 압연 후 그리드의 두께와 각 도의 변화를 측정하여 시편에 가해진 수직변형률과 전단변 형률을 결정하였으며 이 값 들로부터 등가변형률 (equivalent strain, $\varepsilon_{e q}$ )[29-31]을 결정하였다. 등가변형률은 식(1)에 의해 계산되었으며 대칭압연은 두께 감소만큼 길 이가 증가하며 폭의 변화가 0 에 가깝기 때문에 평면변형 (plane strain) 조건이라고 가정할 수 있다. 따라서 식(1)에 서 $\varepsilon_{x}=-\varepsilon_{y}, \varepsilon_{z}=0, \gamma_{y z}=0, \gamma_{z x}=0$ 이 되므로 $\varepsilon_{e q}$ 는 식 (2)와 같이 간단하게 계산될 수 있다. 여기에서 $\theta$ 는 전단변 형각을 의미하며 $\mathrm{d}_{0}$ 와 $\mathrm{d}$ 는 각각 변형 전후 그리드의 두께 를 의미한다.

$$
\begin{aligned}
& \varepsilon_{e q}=\left\{\frac{2\left[\varepsilon_{x}^{2}+\varepsilon_{y}^{2}+\varepsilon_{z}^{2}+\frac{\gamma_{x y}^{2}+\gamma_{y z}^{2}+\gamma_{z x}^{2}}{2}\right]}{3}\right\}^{1 / 2} \\
& \varepsilon_{e q}=\left\{\frac{2\left[\varepsilon_{x}^{2}+\varepsilon_{y}^{2}+\frac{\gamma_{x y}^{2}}{2}\right]}{3}\right\}^{1 / 2}, \gamma_{x y}=\tan \theta, \varepsilon_{y}=-\ln \left(\frac{d}{d_{0}}\right)
\end{aligned}
$$


Table 2. Specimen notation with different heat treatment and rolling conditions.

\begin{tabular}{|c|c|c|c|}
\hline Heat treatment & Rolling method & Rolling temperature & Specimen notation \\
\hline \multirow{6}{*}{ Solution treatment (ST) } & \multirow{3}{*}{ Symmetric rolling (SR) } & Room temperature (RT) & ST-SR (RT) \\
\hline & & $300^{\circ} \mathrm{C}$ & ST-SR (300) \\
\hline & & $500{ }^{\circ} \mathrm{C}$ & ST-SR (500) \\
\hline & \multirow{3}{*}{ Asymmetric rolling (AR) } & Room temperature (RT) & ST-AR (RT) \\
\hline & & $300^{\circ} \mathrm{C}$ & ST-AR (300) \\
\hline & & $500^{\circ} \mathrm{C}$ & ST-AR (500) \\
\hline \multirow{6}{*}{ Aging treatment (AT) } & \multirow{3}{*}{ Symmetric rolling (SR) } & Room temperature (RT) & AT-SR (RT) \\
\hline & & $300^{\circ} \mathrm{C}$ & AT-SR (300) \\
\hline & & $500^{\circ} \mathrm{C}$ & AT-SR (500) \\
\hline & \multirow{3}{*}{ Asymmetric rolling (AR) } & Room temperature (RT) & AT-AR (RT) \\
\hline & & $300^{\circ} \mathrm{C}$ & AT-AR (300) \\
\hline & & $500{ }^{\circ} \mathrm{C}$ & AT-AR (500) \\
\hline
\end{tabular}

\section{3 미세조직 분석}

본 연구에서는 여러 온도에서 수행된 대칭압연, 비대칭 압연에 따른 석출물의 변화를 분석하기 위하여 $\mathrm{X}$-선 회절 기 (XRD, PANalytical Empyrean), 시차주사열량분석기 (DSC, Ta Instruments DSC25)와 투과전자현미경 (TEM, JEOL JEM-ARM200F)이 이용되었다. X-선 회절에는 $\mathrm{CuK} \alpha$ 선을 이용하여 $30 \mathrm{~mA}, 40 \mathrm{kV}$ 에서 $10-100^{\circ}$ 의 범위로 분석되었다. 시차주사열량분석은 아르곤 분위기, $50-400{ }^{\circ} \mathrm{C}$ 온도 범위에서 $10{ }^{\circ} \mathrm{C} / \mathrm{min}$ 의 속도로 승온하면서 진행되었다. $\mathrm{TEM}$ 시편은 $\sim 100 \mu \mathrm{m}$ 두께까지 기계적 연마 후 과염소산 $(10 \%)$ 과 메탄올 $(90 \%)$ 의 혼합용액을 이용하여 $-20^{\circ} \mathrm{C}$, $20 \mathrm{~V}$ 에서 제트폴리싱에 의해 준비되었다.

\section{4 기계적 특성 분석}

압연된 시편들의 기계적 특성은 경도시험을 통해 분석되 었다. 경도시험은 마이크로 비이커스 경도기 (Future-tech, FM-7)을 이용하여 $100 \mathrm{gf}$ 로 시편의 상부 압연면에서 실시 되었으며 각 시편 당 12 번 측정한 후 최대값과 최소값을 제외한 나머지 값들의 평균값을 제시하였다.

\section{5 집합조직 분석}

비대칭압연에 따른 6061 알루미늄 합금의 집합조직 변 화를 분석하기 위하여 EBSD (Electron back scattered diffraction, Oxford, NordlysNano)를 이용하였다. EBSD시 편준비를 위한 전처리로써 먼저 $\mathrm{SiC}$ 페이퍼를 이용하여 2400 번까지 기계적 연마 후 다이아몬드 서스펜션 $(9,3$, $1 \mu \mathrm{m})$ 을 이용하여 추가적인 연마를 실시하였다. 그 후 시 편표면의 잔류응력을 제거하기 위해 콜로이달 실리카
$(0.4 \mu \mathrm{m})$ 현탁액을 사용하여 최종 연마하였다. 압연 시 시 편 위치 (상부롤 부분, 중심부분, 하부롤 부분)에 따른 집 합조직의 차이를 분석하기 위해 시편의 TD (Transverse direction)면을 상부, 중심부, 하부로 나누어 각각 $\mathrm{EBSD}$ 분 석을 실시하였다.

\section{6 성형성과 소성이방성 분석}

비대칭압연에 의해 변화된 집합조직이 6061 알루미늄합 금 판재의 성형성과 소성이방성에 미치는 영향을 알아보기 위해 식 (3)과 같이 정의되는 소성변형비 (plastic strain ratio) r값[32-34]을 측정하였으며, 측정된 $r$ 값을 이용하여 성 형성의 척도인 평균 $\mathrm{r}$ 값 $(\bar{r})$ 과 소성이방성의 척도인 편차 $\mathrm{r}$ 값 $(\Delta r)$ 값을 계산하였다. r값 측정을 위해 ASTM(E517-18) 규격[35]에 따라 그림 4와 같이 압연판재에서 압연방향 $(\mathrm{RD})$ 에 대하여 $0^{\circ}, 45^{\circ}, 90^{\circ}$ 의 각도를 갖는 인장시편을 제

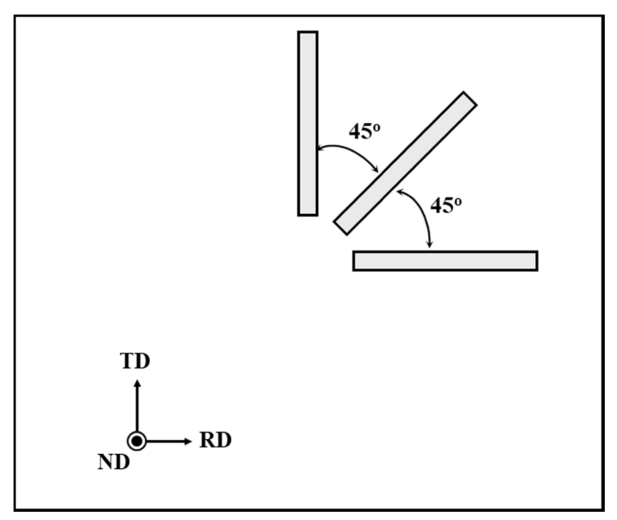

Fig. 4. Schematic picture showing the positions of tensile test specimens taken for determining the r-value. 
(a)

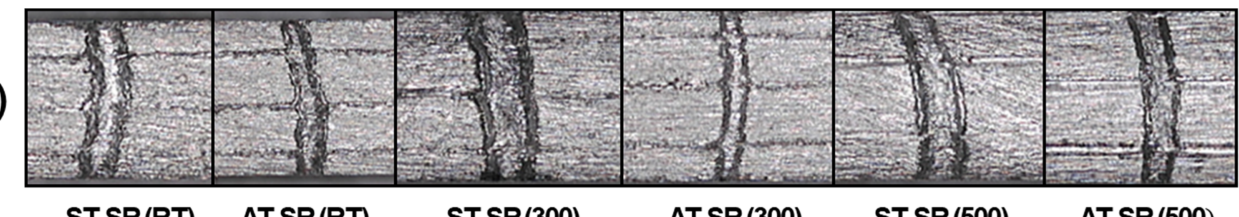

(b)

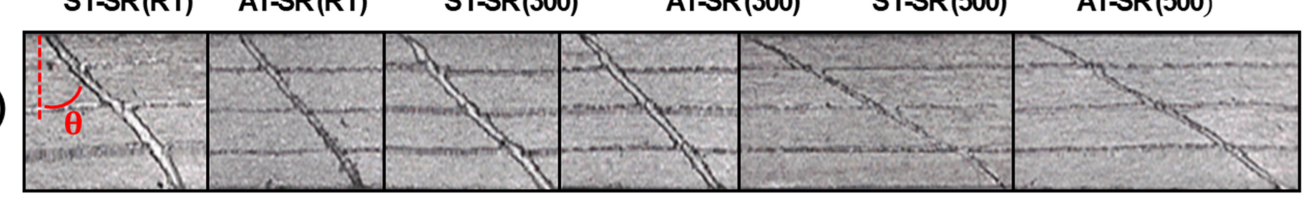

ST-AR(RT)

AT-AR(RT) ST-AR(300)

AT-AR(300) ST-AR(500)

AT-AR(500)
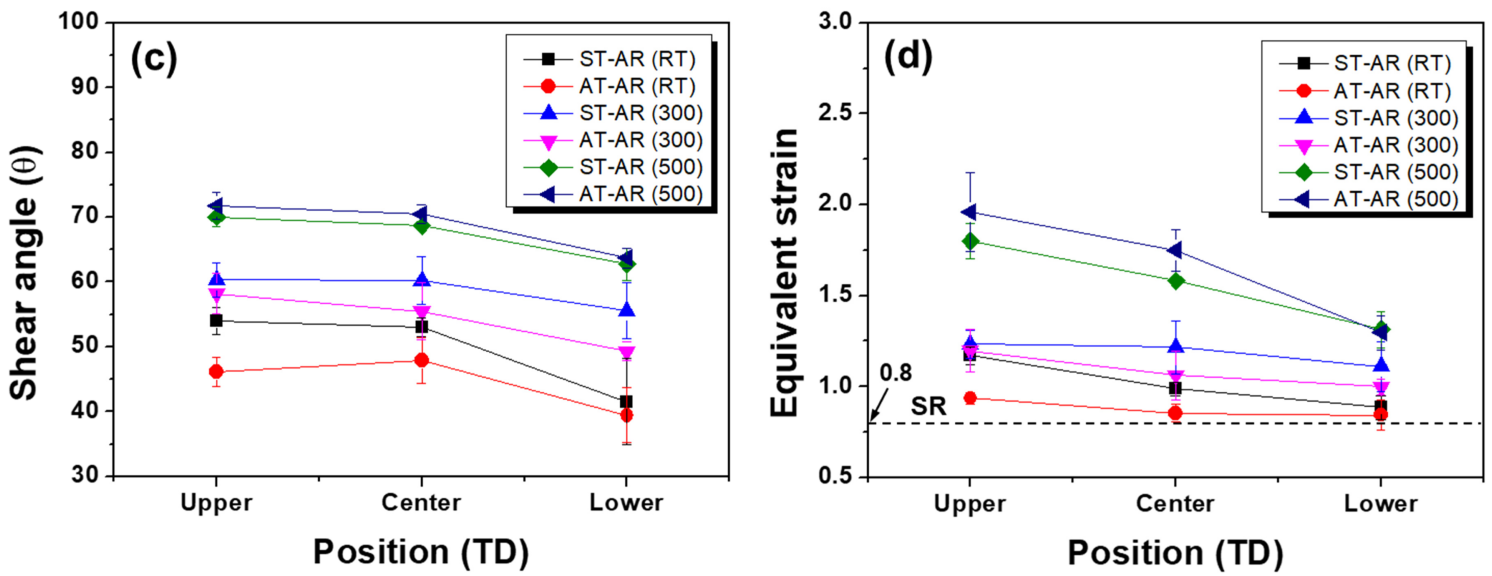

Fig. 5. Deformation patterns obtained from the TD surface of symmetric (a) and asymmetric (b) rolled specimens. The specimen notation is as defined in Table 2. (c) and (d) are variations in shear angle (c) and equivalent strain (d) depending on the position of the rolled specimen.

작하였으며, 인장시험기 (MTDI, MINOS UT-100F)를 이 용하여 상온에서 $10^{-3} / \mathrm{s}$ 의 변형속도로 인장하였다.

$$
\mathrm{r}=\frac{\varepsilon_{w}}{\varepsilon_{t}}=\frac{\ln \left(\frac{w_{f}}{w_{0}}\right)}{\ln \left(\frac{t_{f}}{t_{0}}\right)}=\ln \left(\frac{l_{0} w_{0}}{l_{f} w_{f}}\right)
$$

식 (3)에서 $\varepsilon_{w}, \varepsilon_{t}$ 는 각각 시편의 폭방향과 두께방향의 변형률이며, $w_{0}, w_{f}$ 는 각각 변형 전, 후 시편의 폭방향 크기, $t_{0}, t_{f}$ 는 각각 변형 전, 후 시편의 두께, $l_{0}, l_{f}$ 는 각각 변형 전, 후 시편의 길이를 의미한다. 변형 전, 후 두께의 변화가 매우 작아 측정의 오차를 줄이기 위해 본 연구에서는 식(3)과 같이 두께를 대신하여 시편의 길이를 측정하여 $\mathrm{r}$ 값을 계산하였다. 식(3)으로부터 계산된 $\mathrm{r}$ 값과 식 (4), (5)를 이용하여 평균 $\mathrm{r}$ 값 $(\bar{r})$, 편차 $\mathrm{r}$ 값 $(\Delta \mathrm{r})$ 값을 계 산하였으며, 계산된 $\bar{r}$ 과 $\Delta \mathrm{r}$ 값을 이용하여 시편의 성형성 과 소성이방성을 평가하였다.

$$
\bar{r}=\frac{r_{0}+2 r_{45}+r_{90}}{4}
$$

$$
\Delta \mathrm{r}=\frac{r_{0}+2 r_{45}+r_{90}}{2}
$$

\section{3. 결과 및 고찰}

\section{1 미세조직 변화}

그림 5(a), (b)는 시편의 옆면 (TD면)에 표시된 수직, 수평 그리드 선이 각각 대칭압연과 비대칭압연된 후 변화 된 모양을 보여준다. 그림 $5(\mathrm{a})$ 와 같이 대칭 압연된 경우 두 압연롤과 접촉하는 시편의 윗면과 아랫면 부분을 제외 하고 그리드의 각도 변화가 거의 없었으며 이는 평면변형 압축 (plane strain compression) 변형을 받았기 때문이다. 상부롤과 접촉하는 시편의 윗면과 하부롤과 접촉하는 시편 의 아랫면 부분에서는 수직 그리드의 각도가 약간 변하였 는데 이는 압연롤과 시편사이의 마찰력에 의한 전단변형에 기인한다. 반면 그림 $5(\mathrm{~b})$ 와 같이 비대칭압연된 경우 시편 에 가해진 전단변형에 의해 수직 그리드의 각도변화인 전 단각 $(\theta)$ 의 변화가 발생하였으며, 압연온도가 증가할수록 전단각이 증가함을 알 수 있다. 그림 5(b)로부터 시편의 
상부, 중부, 하부에서 전단각을 측정하였으며 그 결과를 그 림 5(c)에 나타내었다. 또한 그림 5(c)의 전단각과 식(2)를 이용하여 등가변형률을 계산하였으며 그 결과를 그림 5(d) 에 나타내었다. 식(2)에서 알 수 있는 것과 같이 등가변형 률은 전단각 이외에 수직변형률 $\left(\varepsilon_{x}, \varepsilon_{y}\right)$ 에 의해서도 좌우되 지만 모든 시편에 대해 압하율이 $50 \%$ 로 동일하며 그림 5 (b)에서 알 수 있는 것과 같이 비대칭압연 시 각 시편에 서의 그리드 두께 차이가 크지 않아 수직변형률의 차이가 작기 때문에 그림 5(c), (d)에서 알 수 있는 바와 같이 전 단각과 등가변형률의 변화양상은 비슷함을 알 수 있다. 한 편 그림 5(c), (d)에서 알 수 있는 바와 같이 시편의 상부 에서 큰 전단각과 큰 등가변형률을 보여주는데 이는 하부 롤보다 빠른 롤의 회전속도에 기인한다. 또한 압연온도가 증가함에 따라 전단각과 등가변형률이 증가하는데 이는 압 연온도가 증가함에 따라 전단변형이 쉽게 일어나기 때문이 다. 그림 $5(\mathrm{~d})$ 의 하단에 표시한 바와 같이 대칭압연 $(\mathrm{SR})$ 의 등가변형률을 계산해보면 시편의 위치 (상부, 중부, 하 부)에 따라 약간 다르겠지만 전체적으로 $50 \%$ 압하율로 압 연되었으므로 등가변형률은 0.8 이 된다. 따라서 모든 조건 의 비대칭압연은 대칭압연보다 큰 등가변형률을 보이고 있 음을 알 수 있다.

초기석출물이 전단변형에 미치는 영향을 살펴보면 상온에 서 압연한 경우 시편의 위치와 무관하게 초기석출물이 있는 시편 (AT-AR(RT))이 초기석출물이 없는 시편 (ST-AR(RT)) 보다 더 작은 전단각을 보여주고 있다. 이는 시효처리에 의 해 생성된 초기석출물이 비대칭압연 시 전단변형을 방해했 기 때문으로 사료된다. 하지만 고온 $\left(500^{\circ} \mathrm{C}\right)$ 에서 압연할 경 우 반대의 양상을 보인다. 즉, 초기석출물이 존재하는 경우 더 큰 전단변형이 발생하는 것을 알 수 있다. 이는 고온에 서 압연 시 시효가 동반되기 때문이며 이에 대한 자세한 고 찰을 위해 각 시편에 대한 상분석을 진행하였다.

용체화 처리되어 초기석출물이 없는 시편과 peak aging 까지 시효 처리되어 초기석출물이 존재하는 시편을 여러 온도에서 압연할 때 압연하는 동안 발생하는 석출상들의 상변화 거동을 파악하기 위해 $\mathrm{XRD}$ 와 $\mathrm{EDS}$ 를 이용하여 상 분석을 진행하였다. 그림 $6(\mathrm{a} \sim \mathrm{f})$ 는 용체화 처리 후 압연한 시편, 그림 $6(\mathrm{~g} \sim)$ 는 peak aging까지 시효처리 후 압연한 시편의 XRD 분석결과를 보여주며, 그림 7은 6061 알루미 늄 합금의 시효처리 시간에 따른 석출상들의 변화와 그에 따른 강도의 변화를 보여준다. 시효처리 유무와 압연방법 (대칭압연, 비대칭압연)과 무관하게 상온과 $300{ }^{\circ} \mathrm{C}$ 에서 압 연된 시편에서는 안정한 석출상인 $\mathrm{Mg}_{2} \mathrm{Si}(\beta)$ 상이 관찰되지 않았으나 $500{ }^{\circ} \mathrm{C}$ 에서 압연한 시편에서는 모두 $\mathrm{Mg}_{2} \mathrm{Si}(\beta)$
상이 존재함을 알 수 있다. 즉 용체화 처리된 시편은 초기 에는 과포화고용체 상태로 석출물이 존재하지 않았으나 고 온 $\left(500{ }^{\circ} \mathrm{C}\right)$ 에서 압연 시 높은 온도에 의해 안정상인 $\mathrm{Mg}_{2} \mathrm{Si}(\beta)$ 상이 석출되었으며, 시효 처리된 시편은 압연 전 에 이미 생성되었던 준안정상태의 석출물 ( $\beta ")$ 이 고온 $\left(500^{\circ} \mathrm{C}\right)$ 에서 압연하는 동안 안정상인 $\mathrm{Mg}_{2} \mathrm{Si}(\beta)$ 로 변태된 것으로 사료된다. 또한 그림 $6(\mathrm{~g} \sim)$ 에서 알 수 있는 것과 같이 시효처리 된 시편을 상온과 $300{ }^{\circ} \mathrm{C}$ 에서 압연할 때 $\mathrm{Mg}_{2} \mathrm{Si}(\beta)$ 상이 관찰되지 않는 것으로부터 용체화 처리 후 $180{ }^{\circ} \mathrm{C}$ 에서 9시간동안 시효 처리할 때 안정상인 $\mathrm{Mg}_{2} \mathrm{Si}$ ( $\beta$ ) 상이 생성되지 않았으며, $300^{\circ} \mathrm{C}$ 에서 압연할 때에도 생 성되지 않음을 알 수 있다.

그림 8 은 여러 조건에서 압연된 시편들의 $\mathrm{DSC}$ 분석결과 를 보여주며 $50^{\circ} \mathrm{C}$ 에서 $400^{\circ} \mathrm{C}$ 까지 승온하면서 분석되었다. 그림 8(a)는 상온에서 압연한 시편의 온도에 따른 heat flow곡선을 보여준다. 용체화 처리 후 상온에서 압연한 시 편의 경우(ST-SR(RT), ST-AR(RT)) 압연 전에는 아직 석 출물이 형성되지 않았기 때문에 압연형태 (대칭압연, 비대 칭압연)와 무관하게 $\mathrm{DSC}$ 분석 시 온도가 증가함에 따라 $230{ }^{\circ} \mathrm{C}$ 부근에서 준안정상인 $\beta$ ”픽이 관찰된다. 하지만 이 미 시효 처리된 시편의 경우 (AT-SR(RT), AT-AR(RT)) $350{ }^{\circ} \mathrm{C}$ 부근에서 안정상인 $\beta$ 픽이 관찰된다. 이러한 양상은 압연온도가 증가할수록 줄어들게 되며 $500{ }^{\circ} \mathrm{C}$ 에서 압연한 시편들에서는 우선적인 픽이 거의 관찰되지 않음을 알 수 있다. 이 결과는 고온 $\left(500{ }^{\circ} \mathrm{C}\right)$ 에서 압연할 때 이미 안정상 인 $\mathrm{Mg}_{2} \mathrm{Si}(\beta)$ 상이 형성되었기 때문이며 그림 6 의 XRD 분석결과와도 잘 일치한다. 그러므로 $\mathrm{XRD}$ 와 $\mathrm{EDS}$ 분석결 과로부터 시효 처리된 시편들에서는 안정상인 $\mathrm{Mg}_{2} \mathrm{Si}(\beta)$ 상 이 아직 생성되지 않았음을 확인하였으며, 고온 $\left(500{ }^{\circ} \mathrm{C}\right)$ 에 서 압연할 경우 용체화 처리된 시편과 시효 처리된 시편 모두에서 안정상인 $\mathrm{Mg}_{2} \mathrm{Si}(\beta)$ 상이 생성됨을 알 수 있다. 따라서 그림 5(c), (d)에서 보는 바와 같이 초기석출물이 존재할 때 고온 $\left(500{ }^{\circ} \mathrm{C}\right)$ 에서 압연하는 경우 더 큰 전단변 형이 발생하는 이유는 용체화 처리된 시편을 고온에서 압 연할 경우 시효에 의해 석출물이 생성됨에 따라 전단변형 이 어려워지는데 반해 시효 처리된 시편에서는 고온압연 전에 시편은 이미 peak aging 상태 ( $\beta$ ")에 있으므로 고온 압연에 의해 과시효 (overaging)상태에 이르게 되어 강도 가 감소하여 전단변형이 용이하기 때문이다. 그림 9 는 용 체화 처리 후 고온 $\left(500{ }^{\circ} \mathrm{C}\right)$ 에서 비대칭압연된 시편 (ST$\mathrm{AR}(500))$ 과 시효처리 후 고온 $\left(500^{\circ} \mathrm{C}\right)$ 에서 비대칭압연된 시편 (AT-AR(500))의 TEM조직으로 시효 처리된 시편이 용체화 처리된 시편보다 더 큰 $\mathrm{Mg}_{2} \mathrm{Si}(\beta)$ 상을 갖고 있어 

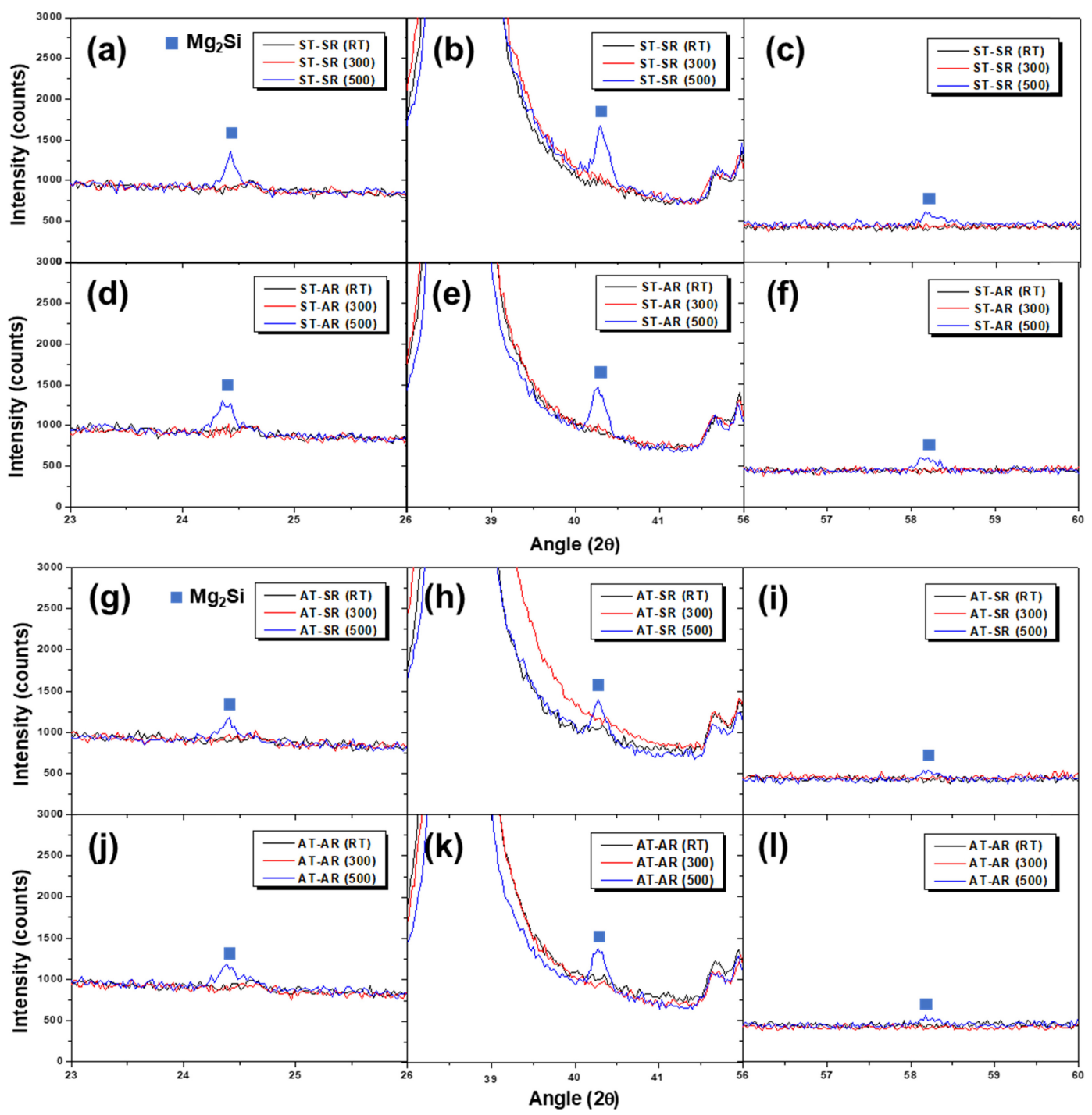

Fig. 6. X-ray diffraction patterns obtained from the symmetric (a-f) and asymmetric (g-l) rolled specimens at RT, $300{ }^{\circ} \mathrm{C}$, and $500{ }^{\circ} \mathrm{C}$.

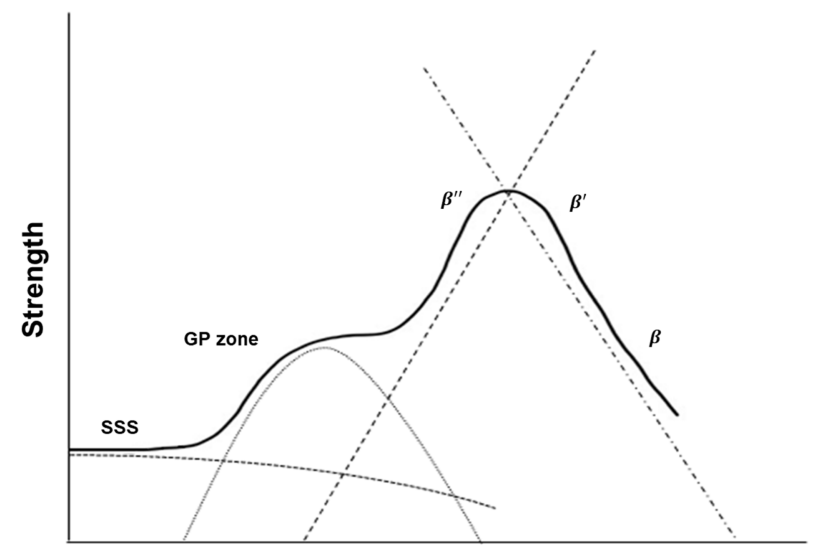

Aging time

Fig. 7. Phase transition and precipitation hardening behavior during aging of 6061 aluminum alloy.
전단변형이 더 용이할 수 있음을 뒷받침한다.

\section{2 경도변화}

그림 10 은 여러 온도에서 대칭압연, 비대칭압연된 시편 들의 경도 값을 나타낸다. 그림에서 알 수 있는 것과 같이 용체화 처리 후 압연한 시편(ST-SR, ST-AR)에서는 압연 전 초기석출물이 존재하고 있지 않아 상온압연 시 석출물 에 의한 경도증가는 없고 가공경화에 의한 경도증가만 존 재한다. 압연온도가 $300{ }^{\circ} \mathrm{C}$ 로 증가할 경우 시효에 의한 석 출물의 생성에 의해 경도가 약간 증가하게 되지만, $500{ }^{\circ} \mathrm{C}$ 에서 압연할 경우 경도는 크게 감소하는데 이는 어닐링 (회 복, 재결정)이 발생했기 때문이다. 반면에 시효처리 후 압 연한 시편(AT-SR, AT-AR)에서는 압연 전 초기석출물이 


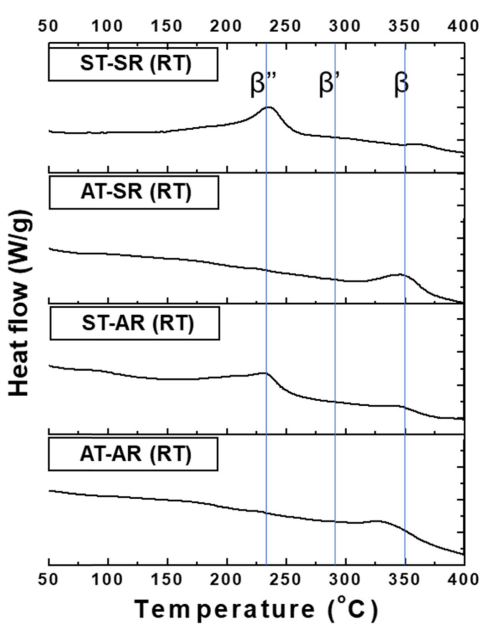

(a)

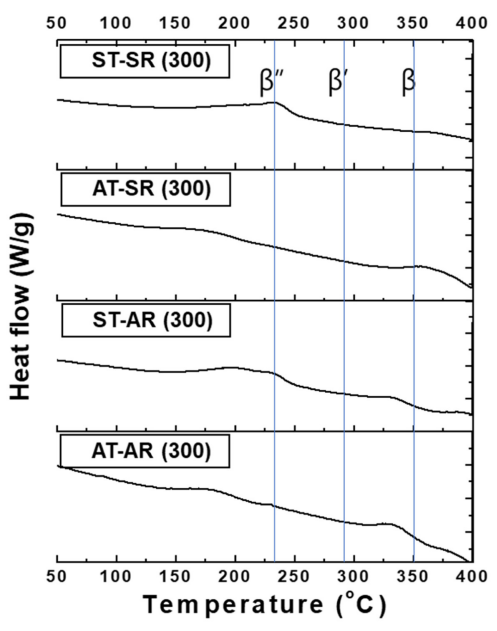

(b)

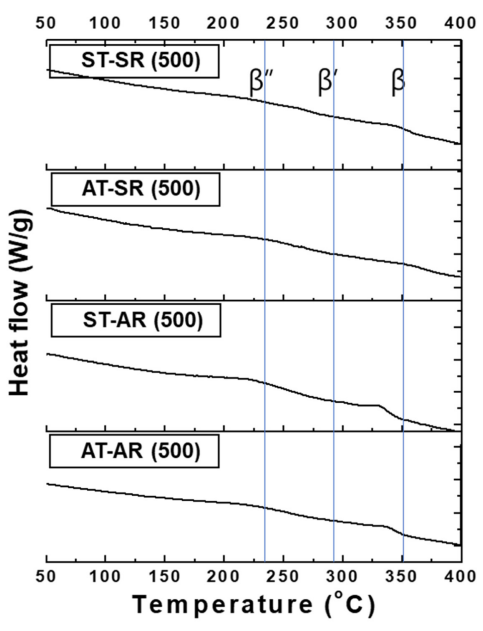

(c)

Fig. 8. Differential scanning calorimetry curves of the symmetric and asymmetric rolled specimens at $\mathrm{RT}(\mathrm{a}), 300{ }^{\circ} \mathrm{C}(\mathrm{b})$, and $500{ }^{\circ} \mathrm{C}(\mathrm{c})$.
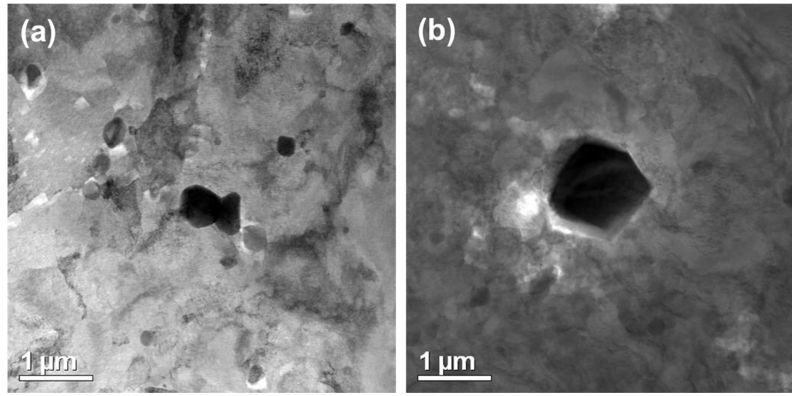

Fig. 9. TEM images showing the $\mathrm{Mg} 2 \mathrm{Si}$ precipitates in the solution treated (a) and aged (b) specimens that are rolled asymmetrically at $500{ }^{\circ} \mathrm{C}$.

존재하므로 상온압연 시 석출물에 의한 경도증가와 가공경 화에 의한 경도증가가 모두 존재하므로 용체화 처리 후 압 연한 시편(ST-SR, ST-AR)보다 높은 경도 값을 갖게 된다. 하지만 $300{ }^{\circ} \mathrm{C}$ 에서 압연한 경우 경도 값이 약간 감소하는 데 이는 그림 7에서 알 수 있는 바와 같이 초기석출물인 $\beta$ "상이 $\beta$ '상으로 과시효가 일어났기 때문으로 사료된다.

한편 비대칭압연 시 초기석출물이 경도 값에 미치는 영 향을 살펴보면 (ST-AR과 AT-AR비교) 상온에서 압연할 때 초기석출물이 존재하는 시편(AT-AR)이 초기석출물이 없는 시편(ST-AR)보다 더 높은 경도 값을 갖는다. 그런데 그림 5(c)에서 ST-AR시편이 AT-AR시편보다 상온에서 더 많은 전단변형을 받음을 언급한 바 있다. 그럼에도 불구하고 그 림 10 에서와 같이 AT-AR시편이 ST-AR시편보다 더 큰 경도 값을 같는 것으로부터 비대칭압연 시 전단변형에 의 한 가공경화효과보다 초기석출물 생성에 의한 석출경화효 과가 시편의 경도증가에 더 크게 기여함을 알 수 있다. 한

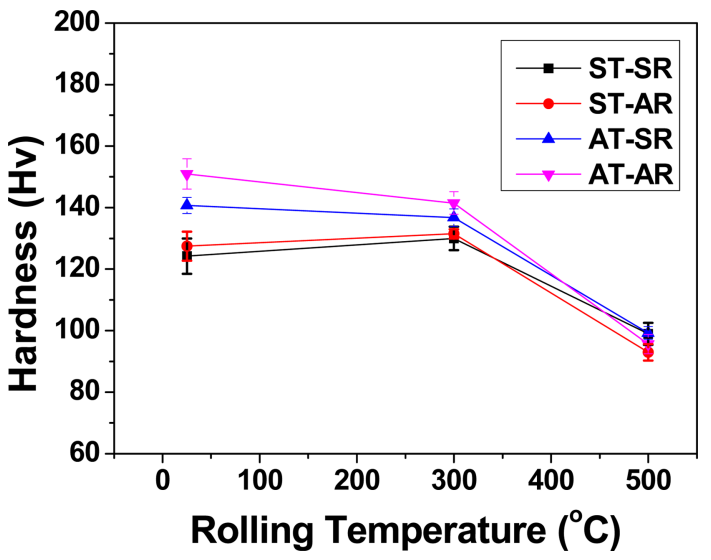

Fig. 10. Variations in Vickers hardness value of the symmetric and asymmetric rolled specimens with rolling temperature.

편 압연온도가 증가할수록 초기석출물이 경도에 미치는 영 향은 점점 줄어듦을 알 수 있다.

\section{3 집합조직 변화}

그림 11 은 $\mathrm{EBSD}$ 를 이용하여 압연조건에 따른 집합조직 의 변화를 극점도 (pole figure, PF), 역극점도 (inverse pole figure, IPF), 방위분포함수 (orientation distribution function, $\mathrm{ODF}$ )를 이용하여 분석한 결과이다. 압연 시 롤 과의 마찰을 받는 시편의 상하부(윗면, 아랫면)와 중심부의 차이를 알아보기 위해 세 영역(상부, 중심부, 하부)으로 나 누어 분석하였다. 용체화 처리 후 대칭압연한 시편 (그림 11(a), (b))에서는 롤과의 마찰에 의해 상부와 하부에서 $\{001\}<110>$ rotated cube 방위와 약한 < $111>/$ ND 집합 조직 $(\{111\}<110>,\{111\}<112>)$ 과 같은 전단집합조직이 

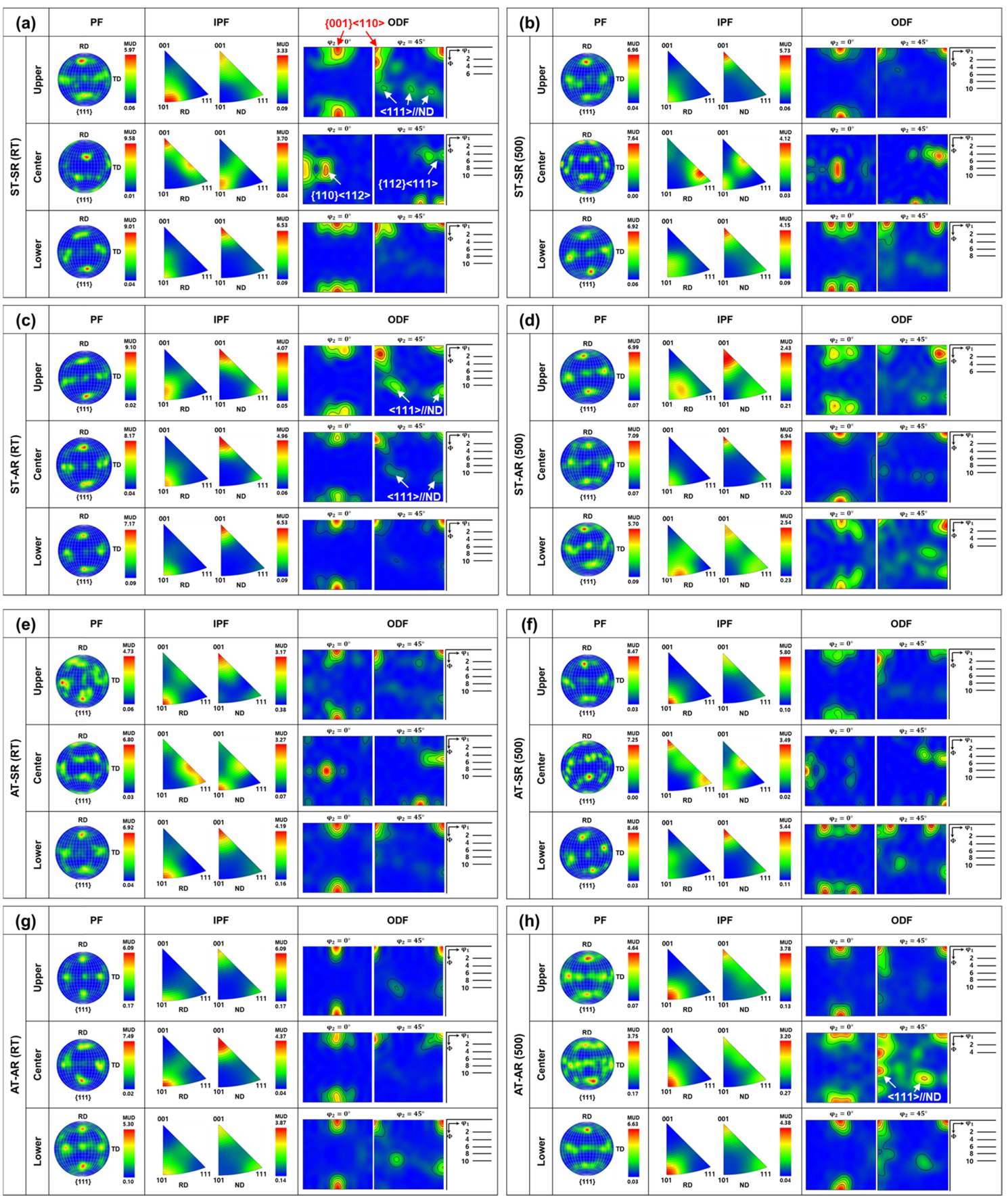

Fig. 11. Pole figure (PF), inverse pole figure (IPF), and orientation distribution function (ODF) for the symmetric and asymmetric rolled specimens. (a) ST-SR (RT), (b) ST-SR (500), (c) ST-AR (RT), (d) ST-AR (500), (e)AT-SR (RT), (f) AT-SR (500), (g) AT-AR (RT), (h) AT$\operatorname{AR}(500)$.

발달하지만, 중심부에서는 Brass방위 $(\{110\}<112>)$ 와 Copper 방위 $(\{112\}<111>)$ 와 같은 전형적인 압연집합조직 이 형성되어 있음을 알 수 있다. 용체화 처리 후 비대칭압 연한 시편 (그림 11(c), (d))에서는 시편의 상부와 하부에서 는 용체화 처리 후 대칭압연한 시편(그림 11(a), (b))과 비
슷한 전단집합조직을 보이지만 중심부에서는 다른 양상을 보이고 있다. 즉, 비대칭압연에 의한 전단변형에 의해 압연 집합조직(Brass, Copper방위)이 나타나지 않고 $\{001\}<110>$, $<111>/ \mathrm{ND}$ 집합조직과 같은 전단집합조직이 생성되었음을 알 수 있다. 따라서 비대칭압연에 의한 전단변형에 의해 
Table 3. $r, \bar{r}$, and $|\Delta \mathrm{r}|$-values predicted for some ideal orientations [33].

\begin{tabular}{lccccc}
\hline \multicolumn{1}{c}{ Ideal orientations } & $r_{0}$ & $r_{45}$ & $r_{90}$ & $\bar{r}$ & $|\Delta \mathrm{r}|$ \\
\hline$\{001\}<100>$, Cube & 1.00 & 0.00 & 1.00 & 0.53 & 0.30 \\
$\{001\}<110>$, Rotated cube & 0.00 & 1.00 & 0.00 & 0.53 & 0.30 \\
$\{111\}<110>,(111) /$ ND & 1.84 & 1.89 & 1.95 & 1.91 & 0.04 \\
$\{111\}<112>,(111) /$ ND & 1.95 & 1.89 & 1.84 & 1.91 & 0.04 \\
$\{110\}<112>$, Brass & 0.50 & 2.09 & 1.00 & 1.35 & 0.46 \\
$\{112\}<111>$, Copper & 1.00 & 1.89 & 0.53 & 1.29 & 0.34 \\
\hline
\end{tabular}

시편의 중심부까지 전단변형이 발생했음을 알 수 있다. 한 편 시효처리 후 대칭압연 (그림 11(e), (f))과 비대칭압연 (그 림 $11(\mathrm{~g}),(\mathrm{h})$ )한 시편은 용체화 처리 후 압연한 시편에서 관찰되는 것과 비슷한 양상의 집합조직을 보여준다. 즉, 비 대칭압연에 의해 시편중심부까지 전단집합조직이 잘 발달 함을 알 수 있다.

비대칭압연 시 초기석출물이 집합조직의 발달에 미치는 영향을 살펴보면 상온과 고온에서의 영향이 다름을 알 수 있다. 먼저 상온에서 압연한 경우를 살펴보면, 초기석출물 이 없는 경우 (그림 11(c)) 상부는 물론 중심부에서도 $<111>/$ ND집합조직이 발달한 반면, 초기석출물이 있는 경 우 (그림 $11(\mathrm{~g})$ ) 중심부에서는 < $111>/ / \mathrm{ND}$ 집합조직이 잘 발달하지 않았음을 알 수 있는데, 이는 그림 5(c)에서 알 수 있는 것과 같이 초기석출물이 없는 시편이 더 많은 전 단변형을 받았기 때문이다. 고온에서 압연한 경우를 살펴 보면, 그림 11(h)에서 알 수 있는 것과 같이 초기석출물이 있는 경우 중심부에서 <111>/ND집합조직이 더 잘 발달하 였는데 이 결과 또한 앞에서 고찰한 바와 같이 더 많은 전단변형을 받았기 때문이다. 그러므로 그림 5(c)에서 알 수 있는 것과 같이 시편에 큰 전단변형을 주기 위해서는 고온 $\left(500{ }^{\circ} \mathrm{C}\right)$ 에서의 비대칭압연이 요구되므로 초기석출물 이 없는 과포화 고용체상태보다 초기석출물이 존재하는 경 우가 큰 전단변형에 의한 강한 전단집합조직의 발달에 더 효과적임을 알 수 있다.

\section{4 성형성과 이방성}

그림 4 와 같이 압연방향에 대해 $0^{\circ}, 45^{\circ}, 90^{\circ}$ 방향으로 인장시편을 제작하여 실시한 인장시험에 의해 얻어진 시편 의 길이, 두께, 폭 방향의 길이변화로부터 식 (3)을 이용하 여 r값을 계산하였으며 그 결과를 그림 12에 나타내었다. 그림 12 에서 알 수 있는 것과 같이 모든 압연조건의 시편 에서 압연방향의 45 도 방향에서의 $\mathrm{r}$ 값 $\left(\mathrm{r}_{45}\right)$ 이 가장 높음을 알 수 있다. 대칭압연한 경우 그림 11에서 알 수 있는 바 와 같이 시편의 상하부를 제외하면 Brass, Copper방위와
같은 전형적인 압연집합조직이 발달하는데 이 방위들은 표 3 과 같이 $r_{0}$ 값과 $r_{90}$ 값에 비해 높은 $r_{45}$ 값을 갖는다. 따라서 이러한 Brass, Copper방위의 발달에 의해 대칭압연한 시편 들은 $\mathrm{r}_{0}$ 값과 $\mathrm{r}_{90}$ 값보다 높은 $\mathrm{r}_{45}$ 값을 갖는다. 한편 비대칭압 연한 경우 그림 11 에서 알 수 있는 바와 같이 전단변형에 의해 < $111>/ / \mathrm{ND}$ 집합조직과 $\{001\}<110>$ 방위가 발달하는데 표 3 과 같이 $\{111\}<110>,\{111\}<112>$ 방위와 같은 $<111>/ / \mathrm{ND}$ 집합조직은 서로 비슷한 $\mathrm{r}_{0}, \mathrm{r}_{45}, \mathrm{r}_{90}$ 값을 보이지 만 $\{001\}<110>$ 방위의 높은 $\mathrm{r}_{45}$ 값으로 인해 비대칭압연한 시편들은 높은 $\mathrm{r}_{45}$ 값을 갖게 된다. 또한 대칭압연한 시편보 다 비대칭압연한 시편이 더 높은 $\mathrm{r}_{0}, \mathrm{r}_{90}$ 값을 보이는데 이 는 대칭압연 시 발달한 Brass, Copper방위는 표 3에서 알 수 있는 것과 같이 낮은 $\mathrm{r}_{0}, \mathrm{r}_{90}$ 값을 갖는데 반해 비대칭압 연 시 발달한 <111>//ND집합조직은 높은 $\mathrm{r}_{0}, \mathrm{r}_{90}$ 값을 갖기 때문이다.

한편 비대칭압연 시 초기석출물이 $\mathrm{r}$ 값에 미치는 영향을 살펴보면, 집합조직의 발달양상과 비슷하게 상온과 고온에 서의 영향이 다르다. 상온에서 압연할 때에는 초기석출물 이 없는 경우가, 고온에서 압연할 때에는 초기석출물이 있 는 경우가 더 높은 $\mathrm{r}_{0}, \mathrm{r}_{90}$ 값을 갖는데 이는 더 큰 전단변 형에 의한 <111>/ND집합조직의 발달에 기인한다.

그림 12 에 보여준 압연시편의 각 방향에서 얻은 $r$ 값으로 부터 식(4), (5)를 이용하여 $\bar{r}$ 값과 $\Delta \mathrm{r}$ 값을 계산하였으며 그 값으로부터 각각 판재의 성형성과 소성이방성을 평가하 였다. 그림 13(a), (b)는 각각 압연방법과 압연온도에 따른 $\bar{r}$ 값과 $\Delta \mathrm{r}$ 값의 변화를 보여준다. 그림에서 알 수 있는 바 와 같이 압연온도의 증가에 따라 $\bar{r}$ 값은 증가하고 $\Delta \mathrm{r}$ 값은 감소하며, 대칭압연한 시편보다는 비대칭압연한 시편이 더 높은 $\bar{r}$ 값과 더 낮은 $\Delta \mathrm{r}$ 값을 가지고 있음을 알 수 있다. 즉, 압연온도가 증가할수록, 비대칭압연을 실시할수록 성형 성 $(\bar{r})$ 이 향상되고 소성이방성 $(\Delta \mathrm{r})$ 은 감소함을 알 수 있 는데 이는 <111>//ND집합조직의 발달에 기인한다. 즉, 표 3 에서 알 수 있는 바와 같이 $\{111\}<110>,\{111\}<112>$ 와 같은 $<111>/ \mathrm{ND}$ 집합조직은 $\mathrm{r}_{0}, \mathrm{r}_{45}, \mathrm{r}_{90}$ 값 모두 1.8 이상의 

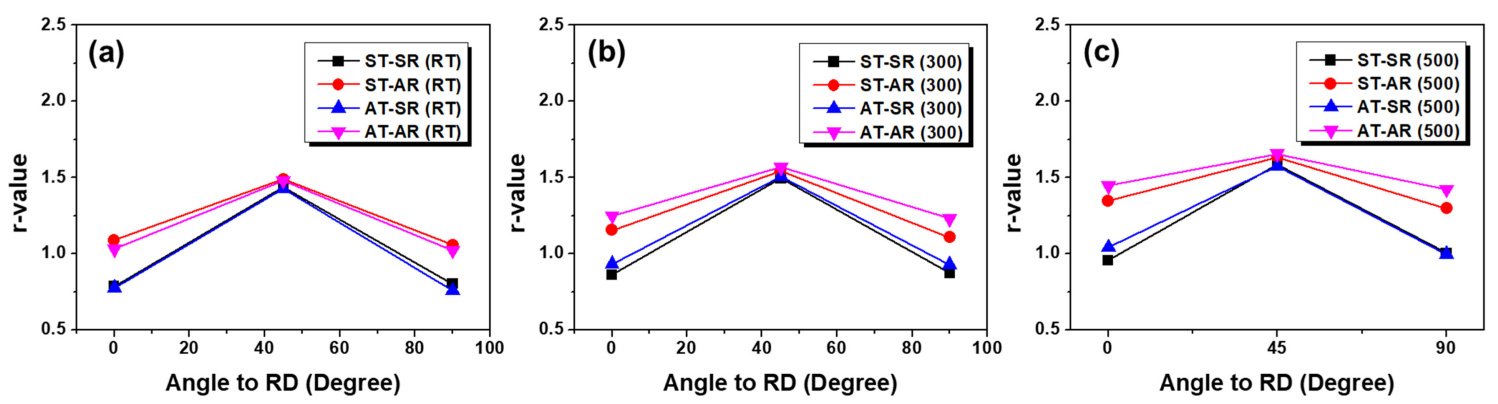

Fig. 12. Variations in the r-values calculated as a function of the angle with respect to the rolling direction for the rolled specimens at RT(a), $300^{\circ} \mathrm{C}(\mathrm{b})$, and $500^{\circ} \mathrm{C}(\mathrm{c})$.
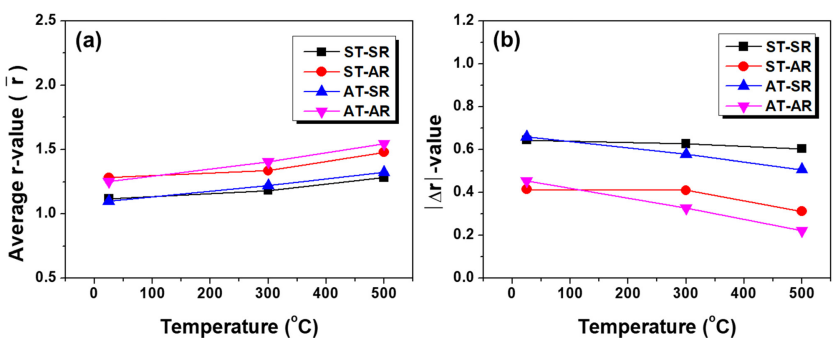

Fig. 13. Variations in average r-value $(\bar{r})(\mathrm{a})$ and $|\Delta \mathrm{r}|$-value (b) as a function of rolling temperature.

높은 값을 갖고 있을 뿐 만 아니라 서로 비슷하므로 높은 $\bar{r}$ 값과 매우 낮은 $\Delta \mathrm{r}$ 값을 갖기 때문이다. 또한 상온에서는 초기석출물이 없는 시편이, 고온에서는 초기석출물이 있는 시편이 <111>/ND집합조직의 발달에 의해 더 높은 $\bar{r}$ 값과 더 낮은 $\Delta \mathrm{r}$ 값을 갖게 된다.

따라서 이러한 결과들로부터 비대칭압연에 의한 <111>/ /ND집합조직의 발달에 의해 6061 알루미늄합금의 성형성 을 향상시키고 소성이방성을 감소시킬 수 있으며, 압연온 도가 높을수록 성형성은 향상되고 소성이방성은 감소됨을 알 수 있다. 또한 초기석출물이 존재하는 시편을 고온에서 비대칭압연하면 성형성 ( $\bar{r}$ 값)을 1.55 까지 증가시킬 수 있 으며, 소성이방성 ( $\Delta \mathrm{r}$ 값)을 0.22 까지 감소시킬 수 있다. 그러므로 비대칭압연에 의해 6061 알루미늄 합금의 성형 성 향상과 소성이방성 감소를 더욱 극대화하기 위해서는 높은 온도에서 비대칭압연을 하는 것이 바람직하며, 과포 화 고용체상태에서 압연하는 것보다 초기석출물이 존재하 는 상태에서 압연하는 것이 더욱 효과적이다.

\section{4. 결 론}

비대칭압연을 이용한 6061 알루미늄 합금의 전단변형 시 초기석출물이 전단변형에 미치는 영향에 대해 연구하였으
며, 전단변형에 의한 집합조직의 변화가 합금의 성형성과 소성이방성이 미치는 영향에 대해 고찰한 결과 다음과 같 은 결론을 얻었다.

1) 비대칭압연은 대칭압연보다 큰 등가변형률을 갖고 있 으며 비대칭압연 시 롤의 회전속도가 빠른 상부롤 부근으 로 갈수록, 비대칭압연 온도가 증가할수록 등가변형률이 증 가한다.

2) 상온에서 비대칭압연할 경우 초기석출물이 있는 시편 이 초기석출물이 없는 시편보다 더 작은 전단변형량을 갖 는데 이는 압연 전 시효처리에 의해 생성된 초기석출물이 압연 시 전단변형을 방해하기 때문이다. 반면에 고온 $\left(500{ }^{\circ} \mathrm{C}\right)$ 에서 압연할 경우 초기석출물이 있는 시편에서 더 큰 전단변형이 발생하는데 이는 초기석출물이 없는 용체화 처리된 시편은 고온에서 압연하는 동안 시효에 의해 석출물 이 생성됨에 따라 전단변형이 어려워져 지는 반면에, 초기 석출물이 있는 시효 처리된 시편에서는 고온압연 전에 존재 하는 준안정상 $(\beta ")$ 이 고온압연동안 과시효 (overaging)되어 강도가 감소하므로 전단변형이 용이하기 때문이다.

3) 상온에서 비대칭압연 시 초기석출물이 존재하는 시편 이 초기석출물이 없는 시편보다 더 작은 전단변형량을 가 짐에도 불구하고 더 높은 경도 값을 갖는데 이는 전단변형 에 의한 가공경화효과보다 초기석출물에 의한 석출경화효 과가 시편의 경도증가에 더 크게 기여했기 때문이다.

4) 비대칭압연에 의한 높은 전단변형량을 갖는 시편에서, 상온압연의 경우 초기석출물이 없는 시편에서, 고온압연의 경우 초기석출물이 있는 시편에서 < $111>/ / \mathrm{ND}$ 집합조직의 발달이 용이하기 때문에 더 높은 $\mathrm{r}_{0}, \mathrm{r}_{90}$ 값을 갖게 되므로 $\bar{r}$ 값 (성형성)은 증가하고 $\Delta \mathrm{r}$ 값 (소성이방성)은 감소한다. 즉, 비대칭압연에 의한 <111>//ND집합조직의 발달에 의해 6061 알루미늄합금의 성형성을 향상시키고 소성이방성을 감소시킬 수 있으며, 성형성 향상과 소성이방성 감소를 더 욱 극대화하기 위해서는 초기석출물이 존재하는 시편을 높 
은 온도에서 비대칭압연을 하는 것이 가장 효과적이다.

\section{감사의 글}

본 연구는 산업통상자원부의 재원으로 한국산업기술진흥 원의 지원을 받아 수행된 연구임. (P0002019, 산업전문인 력역량강화사업)

\section{REFERENCES}

1. R. C. Costa and J. R. Sodre, Fuel 89, 287 (2010).

2. T. Tomoda, T. Ogawa, H. Ohki, T. Kogo, K. Nakatani, and E. Hashimoto, Int. J. Engine. Res. 11, 331 (2010).

3. K. S. Song, S. O. Kang, S. O. Jun, H. I. Park, J. D. Kee, K. H. Kim, and D. H. Lee, Int. J. Automot. Techn. 13, 905 (2012).

4. J. C. Benedyk, 3 - Aluminum alloys for lightweight automotive structures, p.79, Woodhead Publishing, UK (2010).

5. G. S. Cole and A. M. Sherman, Mater. Charact. 35, 3 (1995).

6. G. B. Burger, A. K. Gupta, P. W. Jeffrey, and D. J. Lloyd, Mater. Charact. 35, 23 (1995).

7. M. G. Lyu and T. G. Choi, Int. J. Precis. Eng. Man. 16, 213 (2015).

8. L. Lodgaard and N. Ryum, Mater. Sci. Eng. A 283, 144 (2000).

9. Z. Jia, L. Ding, L. Cao, R. Sanders, S. Li, and Q. Liu, Metall. Mater. Trans. A 48, 459 (2017).

10. S. Pogatscher, H. Antrekowitsch, H. Leitner, T. Ebner, and P. J. Uggowitzer, Acta Mater. 59, 3352 (2011).

11. S. Pogatscher, H. Antrekowitsch, T. Ebner, and P. J. Uggowitzer, TMS Light Metals, 415 (2012).

12. G. A. Edwards, K. Stiller, G. L. Dunlop, and M. J. Couper, Mater. Sci. Forum 217-222, 713 (1996).

13. Y. Kim and S. Kumar, TMS Light Metals, 324 (2020).

14. G. A. Edwards, K. Stiller, G. L. Dunlop, and M. J. Couper, Acta Mater. 46, 3893 (1998).

15. E. Lee, C. Walde, and B. Mishra, Met. Mater. Int. 24, 815 (2018).
16. U. G. Kang and W. J. Nam, Korean J. Met. Mater. 57, 632 (2019).

17. Y. Shi, H. Jin, and P. D. Wu, Eur. J. Mech. A-Solids 69, 1 (2018).

18. W. B. Hutchinson and H.-E. Ekström, Mater. Sci. Technol. 6, 1103 (1990).

19. J. H. Han, K. H. Oh, and J. C. Lee, Mater. Sci. Eng. A 387389, 240 (2004).

20. J. H. Han, J. Y. Suh, K. K. Jee, and J. C. Lee, Mater. Sci. Eng. A 477, 107 (2008).

21. J. Zhang, N. Gao, and M. J. Starink, Mater. Sci. Eng. A 528, 2581 (2011).

22. G. Sha, K. Tugcu, X. Z. Liao, P. W. Trimby, M. Y. Murashkin, R. Z. Valiev, and S. P. Ringer, Acta Mater. 63, 169 (2014).

23. Y. G. Ko and K. Hamad, Metals 7, 494 (2017).

24. J. H. Park, K. Hamad, I. P. Widiantara and Y. G. Ko, Mater. Lett 147, 38 (2015).

25. S. B. Kang, B. K. Min, H. W. Kim, D. S. Wilkinson, and J. Kang, Metall. Mater. Trans. A 36, 3141 (2005).

26. W. J. Kim, J. Y. Wang, S. O. Choi, H. J. Choi, and H. T. Sohn, Mater. Sci. Eng. A 520, 23 (2009).

27. D. C. Magalhães, A. M. Kliauga, M. Ferrante, and V. L. Sordi, Mater. Sci. Eng. A 736, 53 (2018).

28. J. Jiang, Y. Ding, F. Zuo, and A. Shan, Scrip. Mater. 60, 905 (2009).

29. J. H. Park, K. Hamad, I. P. Widiantara, and Y. G. Ko, Mater. Lett. 147, 38 (2015).

30. Q. Cui and K. Ohori, Mater. Sci. Technol. 16, 1095 (2000).

31. N. Kamikawa, T. Sakai, and N. Tsuji, Acta Mater. 55, 5873 (2007).

32. V. K. Barnwal, R. Raghavan, A. Tewari, K. Narasimhan and S. K. Mishra, Mater. Sci. Eng. A 679, 56 (2017).

33. P. H. Lequeu and J. J. Jonas, Metall. Trans. A 19, 105 (1988).

34. J. Hamada, K. Agata, and H. Inoue, Mater. Trans. 50, 752 (2009).

35. ASTM E517-19 Standard Test Method for Plastic Strain Ratio $r$ for Sheet Metal. 